\title{
Enhancing the value of horizon scanning through collaborative review
}

\author{
William J. Sutherland, Hilary Aluison, Rosalind Aveling \\ Ian P. Bainbidge, Leon Bennun, David J. Bullock, Andy Clements \\ Humphrey Q. P. Crick, David W. Gibbons, Sarah Smith, Michael R. W. Rands \\ Paul Rose, Jörn P. W. Scharlemann and Martin S. Warren
}

\begin{abstract}
There is an increased appreciation of the need for horizon scanning: the identification and assessment of issues that could be serious in the future but have currently attracted little attention. However, a process is lacking to identify appropriate responses by policy makers and practitioners. We thus suggest a process and trial its applicability. Twelve environmental conservation organizations assessed each of 15 previously identified horizon scanning issues for their impact upon their organization and the urgency with which they should consider the issue. They also identified triggers that would result in changes in their scoring of the likely urgency and impact of the issues. This process enables organizations to identify priority issues, identify issues they can ignore until there are further developments, benchmark priorities across organizations and identify cross-organizational priorities that warrant further attention, so providing an agenda for collation of evidence, research and policy development. In this trial the review of responses by other organizations resulted in the upgrading of response by a substantial proportion of organizations for eight of the 15 issues examined. We suggest this approach, with the novel components of collaborative assessment and identification of triggers, could be adopted
\end{abstract}

WiLLIAM J. SUTHERLAND (Corresponding author) Conservation Science Group, Department of Zoology, Cambridge University, Downing Street, Cambridge, CB2 3EJ, UK. E-mail w.sutherland@zoo.cam.ac.uk

HILARY AlLISON Woodland Trust, Grantham, UK

Rosalind Aveling Fauna \& Flora International, Cambridge, UK

IAN P. BAINBRIDGE Scottish Natural Heritage, Edinburgh, UK

LEON BENNUn BirdLife International, Cambridge, UK

DAVID J. Bullock The National Trust, Swindon, UK

Andy Clements British Trust for Ornithology, Thetford, UK

HUMPhreY Q.P. CRICK Natural England, Cambridge, UK

DAvid W. GibBons Royal Society for the Protection of Birds, Sandy, UK

Sarah Smith and Michael R.W. Rands Cambridge Conservation Initiative, Cambridge, UK

Paul Rose Joint Nature Conservation Committee, Peterborough, UK

JöRn P. W. SChARLEMANn UN Environment Programme-World Conservation Monitoring Centre, Cambridge, UK

MARTIN S. WARREN Butterfly Conservation, Wareham, UK

Received 3 October 2011. Revision requested 21 November 2011. Accepted 24 November 2011. widely, both within conservation organizations and across a wider range of policy issues.

Keywords Collaboration, conservation, future, horizon scanning, policy, practice, priority setting

\section{Introduction}

$\mathrm{O}$ rganizations currently face a range of well-known issues of varying degrees of urgency and impact. However, there is also a need to reduce the likelihood of being surprised by novel issues. Hence workers in some areas, such as medicine and the arms industry, routinely review emerging technologies and issues (Quiggin, 2007). Governments also undertake routine horizon scanning (van Rij, 2010) and may supplement this by analysing specific areas in more detail (e.g. King \& Thomas, 2007). In view of the problems resulting from past failings to foresee issues and impacts (European Environment Agency, 2001) there have been calls for scanning of future environmental issues (e.g. Holmes \& Clark, 2008; Sutherland et al., 2008; Sutherland \& Woodroof, 2009), including looking at legislative issues (Sutherland et al., 2011a).

Horizon scanning has not been developed with the aim of predicting the future but of examining possible developments, with the objective of considering the likely consequences and the possible responses required (King \& Thomas, 2007; Lawton, 2007). Horizon scanning has been defined as the systematic search for potential threats and opportunities that are currently poorly recognized (Sutherland \& Woodroof, 2009). For example, Sutherland et al. (2010) brought together professional horizon scanners, experts in specific animal and plant groups and representatives of organizations with wide environmental interests to undertake a formal process to identify 15 issues with potential impact on biological diversity that they suggested warranted further consideration (see Sutherland et al., 2011b, for a detailed account of the methods).

Organizations routinely face the challenge of balancing the conflicting demands of current, often well-documented issues, which may require immediate attention, against the consideration of future issues, which may never materialize or may develop slowly, allowing time for appropriate responses in the future. Experience has shown that although 
the concept of horizon scanning may be of interest for those involved in strategic (i.e. policy making) activities there are serious challenges in integrating horizon scanning results with routine (i.e. tactical) decision-making activities (Defra, 2006). Horizon scanning outputs are often not taken up by conservation organizations because the scanning is detached from their established priorities.

Here we suggest an explicit collective process that organizations can use to review and use the results of horizon scanning, thus better linking horizon scanning with its target audiences and their day-to-day decision making. We believe it is novel in two ways. Firstly, although there may be single assessments of impact and urgency we are unaware of any previous collaborative processes of individual assessments. Even collaborative forward planning work undertaken by environmental coalitions such as the Wildlife and Countryside Link has focused purely on a short-term standard opportunities and threats analysis. Secondly, each organization states triggers that would cause it to change the priority with which it may respond to specific horizon scanning issues. This differs considerably from the usual demand for further research. We describe how such a process could operate and trial it by assessing the response of a range of organizations to previously identified horizon scanning issues. Such a collective analysis of horizon scanning can help organizations fully appreciate the consequences of potentially unforeseen issues, and can promote cross-organizational collaboration in responses. The type of process we recommend provides a way of deciding priorities and the timing of possible action by conservation organizations.

\section{The process}

We suggest that there are three main components to the process of responding to horizon scanning (assuming the horizon scanning itself is already completed): (1) ranking of the urgency and impact of issues by individual organizations, (2) sharing of rankings across organizations to allow results to be refined, and (3) publishing and disseminating results so that other organizations can gain from the findings and researchers have the opportunity to study the issues identified as being important.

Many horizon scanning programmes include a process for ranking issues in terms of potential impact and selecting issues for further exploration. Common criteria used include potential impact, and the likelihood or probability of occurrence (SKEP, 2006). For example, Sutherland et al. (2008) assessed each issue according to likelihood, opportunity and threat. The degree of knowledge and level of controversy about an issue has also been used and can signal where more research is needed, or where stakeholder consultation at an early stage would be particularly useful.
TABLE 1 A proposed classification of the issues according to the degree of urgency and potential impact of the issue. Larger circles indicate greater urgency and darker shading higher impact.

\begin{tabular}{ll}
\hline & \begin{tabular}{l} 
Potential impact \\
\cline { 2 - 2 } 1, Non- \\
existent \\
or minor $\quad$ 2, Moderate
\end{tabular} \\
Urgency & \\
\hline 1, Not planning to track & \\
or respond to this \\
issue
\end{tabular}

However, these generic ranking systems typically seek to describe the issue, rather than assess how organizations view it from their perspective. We suggest that from an organizational perspective there are two key aspects to assess: urgency and impact. Urgency distinguishes issues that require some immediate policy development or research from those that can simply be tracked to review their progress. Impact examines effects on the organization's work or concerns (i.e. the extent to which the issue is likely to be important to the organization should it develop).

We designed a classification scheme for ranking issues using the criteria of urgency and impact (Table 1). Impact was divided into three categories: non-existent or minor, moderate, or substantial potential impact.

How urgently the organization plans to respond was divided into six categories: (1) not planning to track or respond to this issue, (2) only likely to respond to this issue if major developments occur, (3) wish to track developments but not take action yet, (4) recognize need for research and policy development, (5) recognize urgent need for research and/or policy implementation or development, (6) committed to responding now through practice or policy work. For urgency, categories 1-3 acknowledge that the organization plans not to take any action beyond tracking developments. Categories 4 and 5 acknowledge the need for research and policy development but not necessarily carried out by 
TABLE 2 A summary, in the original order, of the horizon scanning issues identified by Sutherland et al. (2010), where fuller details and references are given, the percentage of the 12 organizational representatives who had previously heard of each of the issues raised, whether their organizations were involved in the issue prior to the horizon scanning, and the percentage of organizations intending to be involved in the future (i.e. responses at urgency level 4 or above in Table 3 ).

\begin{tabular}{|c|c|c|c|c|}
\hline Issue & Description & $\begin{array}{l}\text { Heard } \\
\text { of }(\%)\end{array}$ & $\begin{array}{l}\text { Involved } \\
(\%)\end{array}$ & $\begin{array}{l}\text { Intending to } \\
\text { be involved (\%) }\end{array}$ \\
\hline Microplastic pollution & $\begin{array}{l}\text { Increased levels of plastic fragments in } \\
\text { seawater, with potential direct impacts } \\
\text { \& impacts through adsorbing pollutants }\end{array}$ & 23 & 25 & 25 \\
\hline Nanosilver in waste water & $\begin{array}{l}\text { Wide use of antimicrobial silver nanoparticles } \\
\text { or ions with potential toxic effects }\end{array}$ & 31 & 8 & 17 \\
\hline Synthetic meat & $\begin{array}{l}\text { Growing meat in laboratories, leading to } \\
\text { reductions in livestock farming }\end{array}$ & 46 & 0 & 0 \\
\hline Artificial life & $\begin{array}{l}\text { Designing microbial genomes, with } \\
\text { potential side-effects should they be released } \\
\text { into the wild }\end{array}$ & 77 & 0 & 8 \\
\hline Stratospheric aerosols & $\begin{array}{l}\text { Putting particles into the stratosphere to } \\
\text { scatter sunlight }\end{array}$ & 54 & 8 & 42 \\
\hline Promotion of biochar & $\begin{array}{l}\text { Burying charcoal to sequester carbon, } \\
\text { with potential consequences for soil properties }\end{array}$ & 85 & 50 & 92 \\
\hline Mobile-sensing technology & $\begin{array}{l}\text { Environmental data collection using mobile } \\
\text { (cellular) phones }\end{array}$ & 69 & 33 & 75 \\
\hline Deoxygenation of the oceans & $\begin{array}{l}\text { Declining oxygen concentration \& expansion } \\
\text { of hypoxic areas }\end{array}$ & 54 & 8 & 50 \\
\hline Changes in denitrifying bacteria & $\begin{array}{l}\text { Sediments switching from being a net sink to } \\
\text { a net source of nitrogen }\end{array}$ & 15 & 8 & 33 \\
\hline High-latitude volcanism & $\begin{array}{l}\text { Increased volcanism in response to loss } \\
\text { of ice sheets }\end{array}$ & 31 & 0 & 8 \\
\hline Invasive Indo-Pacific lionfish & $\begin{array}{l}\text { Predatory Indo-Pacific lionfish in the } \\
\text { western Atlantic }\end{array}$ & 31 & 8 & 0 \\
\hline $\begin{array}{l}\text { Trans-Arctic dispersal } \\
\text { \& colonization }\end{array}$ & $\begin{array}{l}\text { Natural or ship-borne exchange of invasive } \\
\text { species between Pacific \& Atlantic Oceans as } \\
\text { Arctic Ocean ice melts }\end{array}$ & 54 & 17 & 42 \\
\hline Assisted colonization & $\begin{array}{l}\text { Translocation of species to areas outside their } \\
\text { normal range as a response to climate change }\end{array}$ & 92 & 42 & 92 \\
\hline $\begin{array}{l}\text { Possible impact of REDD on } \\
\text { non-forested ecosystems }\end{array}$ & $\begin{array}{l}\text { Potential for enhanced pressure on grassland } \\
\text { \& other habitats }\end{array}$ & 85 & 58 & 67 \\
\hline $\begin{array}{l}\text { Large-scale international } \\
\text { land acquisitions }\end{array}$ & $\begin{array}{l}\text { As countries run out of land \& water } \\
\text { they are buying or leasing land } \\
\text { in other, often developing, } \\
\text { countries }\end{array}$ & 77 & 17 & 58 \\
\hline
\end{tabular}

the organization itself. Category 6 is sufficiently urgent that the organization is committed to action.

The combinations of moderate or substantial impact (on an organization's work or concerns) were considered incompatible with an urgency rating of 'Not planning to track or respond to this issue' (Table 1). However, we retained the combination of committed to responding now through practice or policy work with issues whose impact was identified as non-existent or minor. The logic is that some issues may affect only a minor part of the organization's interests but may still be easy to manage and thus merit an active response. Our methods have three novel components: the quantification of responses, the assessment of triggers that would change classification, and the crossorganizational collation of priorities.

\section{Methods}

This process of classifying impact and urgency was trialled using the 15 horizon scanning issues identified by Sutherland et al. (2010), as summarized in Table 2. A range of organizations was invited to identify representatives to participate in this process. These representatives, who were mostly senior scientists or managers, assessed each issue purely in relation to the concerns of their organization according to the criteria (Table 1 ) by discussing them with relevant policy makers and practitioners within their organizations. They also identified triggers that, if they occurred, would result in their organization upgrading their classification of impact and urgency. They were also asked to state if they had previously heard of each issue and 


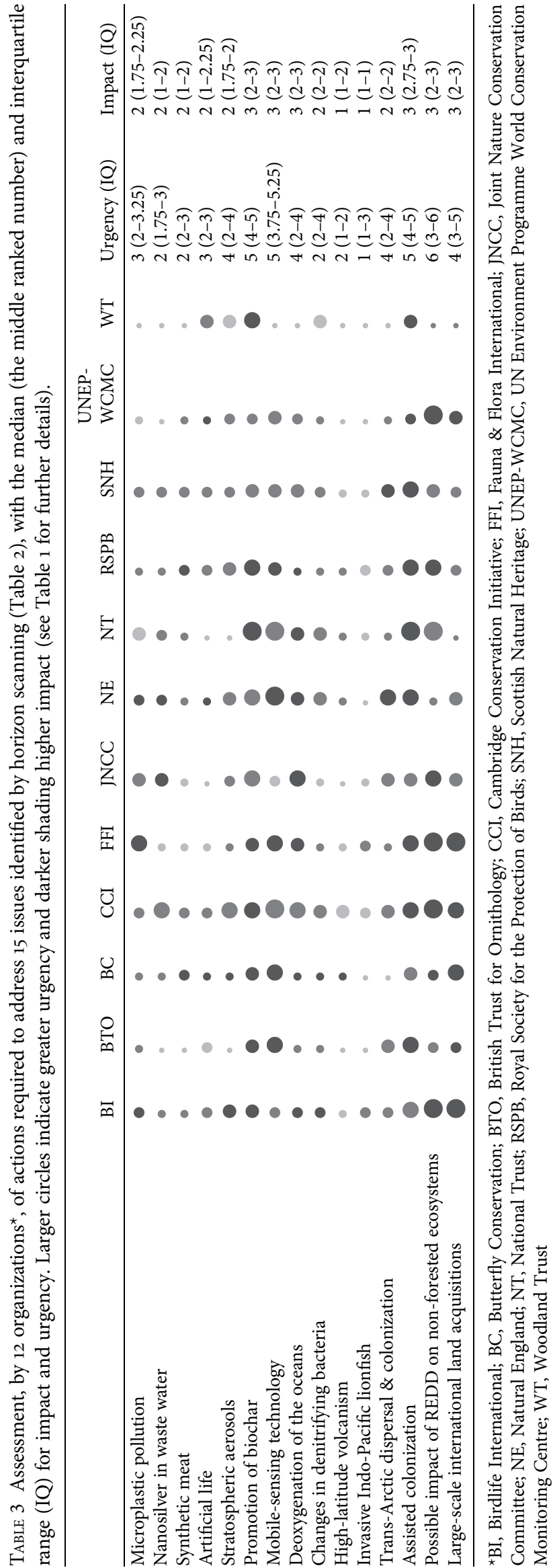

whether their organization was already working on each issue.

The 12 organizations included UK government agencies (Joint Nature Conservation Committee, Natural England, Scottish Natural Heritage), an intergovernmental body (UN Environment Programme-World Conservation Monitoring Centre), UK and international non-governmental organizations (Birdlife International, British Trust for Ornithology, Butterfly Conservation, Fauna \& Flora International, National Trust, Royal Society for the Protection of Birds, Woodland Trust), and the Cambridge Conservation Initiative (via its Director), which is a collaboration between the University of Cambridge and nine conservation organizations, of which five also provided independent assessments of the issues (Birdlife International, British Trust for Ornithology, Fauna \& Flora International, Royal Society for the Protection of Birds, UN Environment Programme-World Conservation Monitoring Centre). The same scoring was used whether the issue was new to the organization or whether they were already aware of it. Organizations' representatives were shown the scores of all other organizations and given the opportunity to rescore.

\section{Results}

Whether the issues had been heard of varied considerably, from changes in denitrifying bacteria, which just $15 \%$ of participants were aware of, to assisted colonization, which 92\% already knew about (Table 2). Twelve of the 15 issues were already being considered by one or several organizations. Only three issues were not being considered by any of the organizations; synthetic meat, artificial life and highlatitude volcanism. The possible impact of reducing emissions from deforestation and forest degradation (REDD) on non-forest habitats was being considered by over half the organizations.

Overall the 12 organizations assessed $24 \%$ of issues as having non-existent or minor, $43 \%$ moderate and $33 \%$ substantial potential impact (Table 3). In terms of urgency, $14 \%$ were classified as not planning to track or respond to these issues, $24 \%$ as only likely to respond if major developments occur, $21 \%$ as wish to track developments but not take action yet, $20 \%$ as recognize need for research and/or policy development, $14 \%$ as recognize urgent need for research and/or policy development, and $7 \%$ as committed to responding now through practice or policy work.

In our two stage process, following examination of the responses of others and further contemplation, the expectations of action were unchanged or only slightly changed $(<10 \%)$ for seven issues but substantially increased $(25-50 \%)$ for the remaining eight.

Organizations differed in the degree to which they considered that responses were needed (Table 3). For example, the Woodland Trust's remit is restricted to 
TABLE 4 Examples of triggers that would cause organizations to reclassify their assessment of urgency and impact of the various horizon scanning issues (Table 2). These triggers will differ considerably between organizations according to their sphere of interest. Abbreviations of organizations as beneath Table 3 .

\begin{tabular}{|c|c|}
\hline Issue & Examples of reclassification triggers \\
\hline Microplastic pollution & $\begin{array}{l}\text { Threshold trigger of high perceived or real impact in human food chain/food webs (NT) } \\
\text { Evidence of population level impacts (FFI) }\end{array}$ \\
\hline Nanosilver in waste water & $\begin{array}{l}\text { When ecosystem effects are noticeable, e.g. effects on fish embryos (JNCC) } \\
\text { Evidence of direct impacts \& toxicity further up the food chain (FFI) }\end{array}$ \\
\hline Synthetic meat & $\begin{array}{l}\text { Substantial decline in production costs \&/or reduced income of livestock graziers }(\mathrm{BC}) \\
\text { If production was such that changes to land use in England were a potential reality (NE) }\end{array}$ \\
\hline Artificial life & $\begin{array}{l}\text { Noticeable contribution to ecosystem functions at any scale (JNCC) } \\
\text { Evidence that this might affect the long-term sustainability of ecosystems/species (SNH) }\end{array}$ \\
\hline Stratospheric aerosols & $\begin{array}{l}\text { Government/company starts putting aerosols in atmosphere (RSPB) } \\
\text { Serious consideration by anyone to implement this as a climate change mitigation strategy } \\
\text { (UNEP-WCMC) }\end{array}$ \\
\hline Promotion of biochar & $\begin{array}{l}\text { Subsidies become available for biochar to reduce climate change (BC) } \\
\text { Promoted by its inclusion in post-Copenhagen agreements (RSPB) }\end{array}$ \\
\hline Mobile-sensing technology & $\begin{array}{l}\text { Development of 'app' (software made for mobile phones) that collates records with date \& } \\
\text { location (BC) } \\
\text { Development of an 'app' to identify 'difficult' species, such as bats, from their calls (NE) }\end{array}$ \\
\hline Deoxygenation of the oceans & $\begin{array}{l}\text { Clear evidence of ecosystem-level effects with potential to affect bird populations (BI) } \\
\text { Impacts observed in UK waters (JNCC) }\end{array}$ \\
\hline Changes in denitrifying bacteria & $\begin{array}{l}\text { Clear evidence of ecosystem-level effects with potential to affect bird populations (BI) } \\
\text { If there is more evidence that this is likely to happen in Scotland (SNH) }\end{array}$ \\
\hline High-latitude volcanism & $\begin{array}{l}\text { Modelling points to major volcanic eruption that causes ice cap meltdown (NT) } \\
\text { If volcanism occurs \& there are significant impacts on local climate/weather/sea level/sea } \\
\text { composition (NE) }\end{array}$ \\
\hline Invasive Indo-Pacific lionfish & $\begin{array}{l}\text { Clear evidence of ecosystem-level effects with potential to affect bird populations (BI) } \\
\text { Increased evidence of dispersal from Caribbean \& establishment in north-west Europe \& } \\
\text { Mediterranean (NT) }\end{array}$ \\
\hline Trans-Arctic dispersal \& colonization & $\begin{array}{l}\text { When the Arctic becomes substantially ice-free \& there is evidence for faunal/floral colonization } \\
\text { into Atlantic (NE) } \\
\text { Recorded species movements, either naturally or via shipping (FFI) }\end{array}$ \\
\hline Assisted colonization & $\begin{array}{l}\text { First large-scale introduction of species outside its current range but within its predicted climate } \\
\text { space (RSPB) } \\
\text { Given that this is likely to happen, our approach might change where there is evidence that it is } \\
\text { not working/going to work, or is going to cause problems for existing ecosystems or species } \\
\text { (SNH) }\end{array}$ \\
\hline $\begin{array}{l}\text { Possible impact of REDD on non- } \\
\text { forested ecosystems }\end{array}$ & $\begin{array}{l}\text { If REDD/avoided deforestation incorporated into post-Copenhagen deal \& no similar deal for } \\
\text { peatlands, for example (RSPB) } \\
\text { Evidence of indirect land use change (UNEP-WCMC) }\end{array}$ \\
\hline $\begin{array}{l}\text { Large-scale international land } \\
\text { acquisitions }\end{array}$ & $\begin{array}{l}\text { Evidence of accelerated land acquisition \& intensification of land use (BC) } \\
\text { Evidence that these land acquisitions will have negative impact on biodiversity (UNEP-WCMC) }\end{array}$ \\
\hline
\end{tabular}

woodland conservation in the UK and as such many of the issues, such as those relating to marine environments, are not relevant to them. At the other extreme, some of the large international organizations, such as BirdLife International, have programmes around the world in a wide range of habitats and thus most of the topics are relevant to some part of the organization. The issues varied markedly in the extent to which organizations considered them to be urgent and of high impact (see Table 3 for the mediation scores). The issues with the greatest immediate impact were the promotion of biochar, deoxygenation of the oceans, assisted colonization, and the impact of REDD on nonforest ecosystems. The spread of invasive lionfish and high latitude volcanism were considered to have the lowest impact.

Organizations identified triggers that would probably cause them to change their classifications of issues (Table 4), and found this exercise useful in clarifying what aspects they may need to remain alert to for each issue, even if not tracking an issue in detail. Many of the triggers relate to changes in evidence. This should not be seen as a research prioritization exercise but, rather, should research change the evidence in the way stated, then the issue would be reclassified.

This horizon scanning for new issues is being repeated annually. We plan to coordinate the routine assessment of 
the output, using the methods described here, with the assessment placed on the Cambridge Conservation Initiative website.

\section{Discussion}

As horizon scanning becomes more widespread in a range of areas, including medicine (Storz et al., 2007; Gwinn et al., 2011), epidemiology (Morgan et al., 2009), business (Brown, 2007), and criminology (White \& Heckenberg, 2011), as well as conservation (Sutherland et al., 2010), there is a need to think clearly about how information from scans can be used by organizations. Horizon scanning can be used as part of 'adaptive foresight' (Eriksson \& Weber, 2008): instruments that deliberately challenge policy makers to look at the uncertainties and the unexpected and develop resilient policies towards sustainability (van Rij, 2010). The 12 conservation organizations showed wide variation in action on particular issues (Table 2). Although some action (or inaction) may already have been based on the results of horizon scanning, in most cases our experience is that it results from a more ad hoc process and, in the case of doing nothing, to limitations in the ability to consider and assess these issues. The process outlined here provides a means whereby a decision to do nothing, to continue as before or to raise the level of engagement becomes active and based on the examination of information.

Only three of the 14 authors were also authors of the original horizon scanning exercise (Sutherland et al., 2010). The high ranking of the issues showed that the original exercise had succeeded in identifying issues that were generally of concern to policy makers and practitioners. Furthermore the public nature of such an exercise allows organizations to benchmark (Keehley \& Abercrombie, 2008; Sutherland \& Peel, 2011) their assessment against that of others, especially those with similar objectives, and to reflect further on the impact and urgency they are assigning each issue. This also leads to opportunities to collaborate by sharing reviews of horizon scanning, alerting those with similar concerns over any changes or joining forces to conduct in depth research into issues (van Rij, 2010).

Organizations will differ in the extent to which it is appropriate for them to respond to horizon scanning, depending upon the breadth of their interests. However, by undertaking the process described in this paper, which brings together a wide range of organizations that are likely to be affected by the issues concerned, there are three additional benefits. Firstly, where there is a broad level of agreement that an issue is of widespread concern national or international bodies are provided with the impetus to undertake further research in the area. For example, within the UK, government departments or national research councils could sponsor research to help develop the relevant evidence base. Secondly, some of the organizations that undertook the review independently may see common interests with others, and pool resources to undertake further work on an issue, thereby facilitating a more effective use of financial resources. Thirdly, researchers may respond to the identification and prioritization of issues by carrying out research or review, or by promoting the issues.

However, we have some general caveats. Conservation organizations are typically very busy and with severely stretched resources. Although the rankings of organizations were based on internal consultations it may be difficult to engage the organizational leadership, including both nonexecutive board members and executive directors, widely and deeply enough to ensure genuine commitment. Given the pressure of other priorities it is also not clear that management will necessarily stand behind prioritized issues with resources and actions. These practical issues are likely to result in a gap between knowing that an issue is important and doing something substantive to address it. It will be important to assess the value and effectiveness of this collaborative horizon scanning assessment by monitoring whether the organizations involved acted on the issues identified, modified their responses to changing conditions, or acted in a collaborative manner to react to issues of common concern.

We are aware of three disadvantages of horizon scanning and assessing priorities in the manner we describe. Firstly, if done inappropriately it could result in too much effort being spent contemplating improbable issues far ahead, to the detriment of more immediate and important considerations. Secondly, the rational process of explicitly deciding not to act on some issues may appear callous to some audiences, such as an organization's membership or employees. Thirdly, this process is probably easiest for organizations with narrow objectives, constrained, for example, by taxon, habitat or region. Two large global organizations, although supportive of the process, decided that it would be too impractical for them to assess these issues in relation to their multitude of global interests.

\section{Acknowledgements}

We thank the individuals within the various organizations who helped with the assessment of the priorities, Stephanie Prior for collating the scores, Kent Redford and Mark Spalding for discussion of the process and the referees and Martin Fisher for useful suggestions. This is an activity of the Cambridge Conservation Initiative. William Sutherland is funded by the Arcadia fund.

\section{References}

Brown, D. (2007) Horizon scanning and the business environmentthe implications for risk management. BT Technology Journal, 25, 208-214. 
Defra (Department for Environment, Food and Rural Affairs) (2006) Looking Back at Looking Forwards: Next Steps for Horizon Scanning and Futures. Horizon Scanning and Futures Team, Science Economics and Statistics DG, Defra, London, UK.

ERIKSSON, E.A. \& WEBER, K.M. (2008) Adaptive foresight: navigating the complex landscape of policy strategies. Technological Forecasting and Social Change, 75, 462-482.

European Environment Agency (2001) Late Lessons from Early Warnings: The Precautionary Principle 1896-2000. Environmental Issue Report No 22. Office for Official Publications of the European Communities, Luxembourg.

Gwinn, M., Grossniklaus, D.A., Yu, W., Melillo, S., Wulf, A., Flome, J. et al. (2011) Horizon scanning for new genomic tests. Genetics in Medicine, 13, 161-165.

Holmes, J. \& CLARK, E. (2008) Enhancing the use of science in environmental policy-making and regulation. Environmental Science Policy, 11, 702-711.

Keehley, P. \& Abercrombie, N.N. (2008) Benchmarking in the Public and Nonprofit Sectors, 2nd edition. Wiley, San Francisco, USA.

KInG, D.A. \& Thomas, S.M. (2007) Taking science out of the box -foresight recast. Science, 316, 1701-1702.

LAWTon, J.L. (2007) Ecology, politics and policy. Journal of Applied Ecology, 44, 465-474.

Morgan, D., Kirkbride, H., Hewitt, K., Said, B. \& Walsh, A.L. (2009) Assessing the risk from emerging infections. Epidemiology and Infection, 137, 1521-1530.

Quiggin, T. (2007) Seeing the Invisible: National Security Intelligence in an Uncertain Age. World Scientific Publishing, Singapore.

SKEP (Scientific Knowledge for Environmental Protection) (2006) How to Identify Emerging Long-term Strategic Issues for Environmental Research and Policies: a Diversity of Possible Approaches. Report on current practices for research planning and 'horizon-scanning' in member states. SKEP ERA-net project: Scientific Knowledge for Environmental Protection.

Storz, P., Kolpatzik, K., Perleth, M., Klein, S. \& Haussler, B. (2007) Future relavance of genetic testing: a systematic horizon scanning analysis. International Journal of Technology Assessment in Health Care, 23, 495-504.
Sutherland, W.J., Bailey, M.J., Bainbridge, I.P., Brereton, T., Dick, J.T.A., DrewitT, J. et al. (2008) Future novel threats and opportunities facing UK biodiversity identified by horizon scanning. Journal of Applied Ecology, 45, 821-833.

Sutherland, W.J., Barlow, R., Clements, A., Harper, M., Herkenrath, P., Margerison, C. et al. (2011a) What are the forthcoming legislative issues of interest to ecologists and conservationists in 2011? BES Bulletin, 1, $26-31$.

Sutherland, W.J., Clout, M., Côté, I.M., Daszak, P., Depledge, M.H., Fellman, L. et al. (2010) A horizon scan of global conservation issues for 2010. Trends in Ecology \& Evolution, $25,1-7$.

Sutherland, W.J., Fleishman, E., Mascia, M.B., Pretty, P. \& RudD, M.A. (2011b) Methods for collaboratively identifying research priorities and emerging issues in science and policy. Methods in Ecology and Evolution, 3, 229-332.

Sutherland, W.J. \& Peel, M.J.S. (2011) Benchmarking as a means of improving conservation practice. Oryx, 45, 56-59.

Sutherland, W.J. \& Woodroof, H.J. (2009) The need for environmental horizon scanning. Trends in Ecology \& Evolution, 24, $523-527$.

VAN RiJ, V. (2010) Joint horizon scanning: identifying common strategic choices and questions for knowledge. Science and Public Policy, 37, 7-18.

White, R. \& Heckenberg, D. (2011) Environmental horizon scanning and criminological theory and practice. European Journal on Criminal Policy and Research, 17, 87-100.

\section{Biographical sketches}

The authors are academics, practising conservationists from conservation organizations, or members of environmental research organizations. Many are members of the Cambridge Conservation Initiative. This article is a component of the horizon scanning programme of the Cambridge Conservation Initiative, which seeks to identify forthcoming issues in conservation. 